\title{
Comparison of Standard and \\ Organic Pesticides as Well as Herbal \\ Products for Control of Insect Pests of \\ Cabbage (Brassica oleracea) in \\ Saskatchewan
}

Sarah J. Wist*

\begin{abstract}
Many insect pests can potentially damage cabbage (Brassica oleracea) grown in Saskatchewan. Root maggots (Delia spp), flea beetles (Phyllotreta spp) and cabbage worms (Order: Lepidoptera) are the main concerns. The objective of this project was to assess the potential to use of companion planted herbs or herbal essential oils as control methods for these pests. Standard synthetic pesticides were used as a check treatment. Organic pesticides and a row cover were also tested and compared to an untreated control. The herbal treatments were garlic or thyme plants interplanted with the cabbage crop along with foliar sprays of garlic or thyme oil. The pest control treatments were compared in trials using both transplanted and direct seeded cabbage. The standard and organic pesticide regimes both effectively controlled all three of the insect pests, and resulted in similar head yields in both the transplanted and direct seeded cabbage crops. The row cover successfully prevented insect damage but created problems with weed control and required extra materials and labour to construct. The microclimate created by the row cover decreased growth of the direct seeded crop. None of the herbal products provided effective control of any of the insect pests of cabbage. In conclusion, cabbage can be successfully grown in Saskatchewan with minimal losses to insects using either standard synthetic or organic pesticides, but the herbal were not effective in the form and rates tested in this project.
\end{abstract}

Keywords: cabbage, garlic, thyme, organic agriculture, pesticide, companion planting, horticulture, Delia radium, Tricoplusia ni, Phyllotreta cruciferae

*Department of Horticultural Science, College of Agriculture and Bioresources, University of Saskatchewan, Saskatoon, SK, Canada Correspondence: sarah.wist@mail.usask.ca 
Cabbage is closely related to canola (Brassica napus and $B$. rapa), and the two crops share many of the same insect pests including root maggots (Delia spp), flea beetles (Phyllotreta cruciferae and P. striolata), cabbage loopers (Tricoplusia ni) and imported cabbage worms (Pieris rapae). It is recommended that cabbage growers have a crop rotation of three or more years way from cruciferous crops to control these pests (Saskatchewan Agriculture and Food 2005). Canola presently covers approximately one third of the cropland in Saskatchewan (Statstics Canada 2015a); therefore implementing an effective crop rotation to minimize insect pests in cabbage is difficult. Insecticides or other pest control measures are typically necessary to control these insect pests in cabbage grown in Saskatchewan.

Delia radicum, which is the primary species of root maggot in Saskatoon, prefers cabbage as a host plant over canola (Soroka and Dosdall 2011). Delia radicum is generally univoltine on the Canadian prairies, with peak egg laying in June (Broatch et al. 2006). The maggots feed on the host plant's roots, resulting in wilting, stunted growth and, in cases of severe infestation, death. Roots damaged by root maggot feeding are also susceptible to secondary infections by pathogens such as Fusarium spp. (Soroka and Dosdall 2011).

The three main flea beetle species (Coleoptera: Chrysomelidae) present in western Canada are the crucifer flea beetle (Phyllotreta cruciferae), the striped flea beetle ( $P$. striolata) and the hop flea beetle (Psylliodes punctulata) (Canola Council of Canada 2014b). Flea beetles have one generation per year in western Canada, with the greatest damage occurring in May and June. Flea beetle feeding causes the most damage at the cotyledon and early true leaf stages of canola (Canola Council of Canada 2014b). To avoid flea beetle problems, cabbage producers can use transplants as larger plants are less sensitive to flea beetle feeding damage than newly emerged seedlings (Soroka 1984).

The larvae of the imported cabbage worm (Pieris rapae), cabbage looper (Tricoplusia ni) and diamondback moth (Plutella xylostella) all feed on cabbage in Saskatchewan (Saskatchewan Agriculture and Food 2005). All three of these insects have multiple generations per year in Saskatchewan (Canola Council of Canada 2014a).

The only insecticide currently registered for control of root maggots in cabbage grown in Canada is chlorpyrifos. The Pest Management Regulatory Agency (PMRA) is trying to minimize the amount of chlorpyrifos used in Canada because of harmful effects on the applicator and the environment (PMRA 2007). Additionally, $75 \%$ of the root maggot populations in British Columbia in 2013 were found to be resistant to chlorpyrifos. This type of resistance is increasing across Canada (Agriculture and Agri-Food Canada 2015).
Various parasitic nematodes have been shown to attack root maggots. For example, Steinernema feltiae was reported to offer some level of root maggot control in both field and greenhouse studies (Bracken 1990; Leger and Riga 2009). However, Waterer (1998) reported that applying nematodes did not significantly improve marketable yields in field grown rutabagas in Saskatchewan over a nontreated control.

There are several pesticides available for control of flea beetles in brassica vegetables in Canada (Ontario Ministry of Agriculture and Food 2013). Early seeding is also recommended as a cultural control option for canola as the plants may emerge before the flea beetles and larger plants are better able to tolerate flea beetle damage (Canola Council of Canada 2014b). This concept is the reason that some growers use transplants to establish their cabbage crops. No organic products are available to control flea beetles.

There are many insecticides registered for control of cabbage loopers, imported cabbage worms and diamondback moths including carbamates and pyrethroids. However, these popular pesticides are no longer effective for looper control in some areas of Canada (Ontario Ministry of Agriculture and Food 2013). Bacillus thuringiensis subspecies kurstaki (Btk) is an organically approved biological control agent widely used against Lepidopteran pests, such as cabbage loopers. The Btk bacteria must be ingested by the larvae and reacts with the alkaline environment of the insect's gut to become toxic. The Btk toxin is not activated in mammalian guts and it is therefore very safe to apply (Pest Management Regulatory Agency 2000). Due to widespread use and overreliance on Btk, $P$. xylostella has developed resistance in the field and $T$. ni has developed resistance in vegetable production greenhouses (Janmaat and Myers 2003). Spinosad is another organically acceptable insecticide for control of cabbage worms. It is produced by fermentation of the soil actinomycete Saccharopolyspora spinosa. Spinosad has a unique mode of action among insecticides, making cross-resistance with other insecticides highly unlikely. However, some resistance problems have been reported in a variety of insect pests and locations (Kirst 2010). Spinosad has fewer environmental effects and is safer to use than other insecticides (Kirst 2010).

\section{Companion Plants and Essential Oils for Insect Control in Cabbage}

Companion planting is based on the theory that planting certain combinations of plants together will offer some benefit to one or both plant species being grown (Philbrick and Gregg 1966). Commonly this benefit is deterring pests. Garlic, along with other aromatic herbs, is often 
recommended as a companion plant to repel insects as it has a strong odour (Roth 1999), which may interfere with the insect pest's ability to locate its preferred host crop (Zehnder et al. 1997).

Companion plants and essential oils may deter root maggot and cabbage worm egg laying, and flea beetle feeding. All three pests locate and accept host plants based on plant chemistry, including volatile chemical signals (Bruce et al. 2005; Henderson et al. 2004). For example, cabbage worm adults must detect a certain ratio of plant volatiles to locate suitable host plants (Bruce et al. 2005). Essential oils could potentially alter the ratio of plant volatiles enough to cause pests to falsely reject host plants. In addition, Finch et al. (2003) found that having non-host plants surrounding a Brassica host plant reduced the number of eggs laid on the host plant by $D$. radicum. In lab experiments, both thyme oil and garlic oil have been shown to be directly toxic to cabbage looper larvae (Jiang et al. 2010; Tak et al. 2015; Machial et al. 2010).

Row covers can prevent all three types of insect pests from damaging the cabbage crop. Row covers are used to cover the crop plants and modify the growing environment in some way, depending on the thickness, colour and material used. In this paper 'row cover' refers to a lightweight, white agrotextile used as a physical barrier over and around the crop. This type of row cover is used to protect against insect attack as the insects will not be physically able to reach the crop plants.

The goal of this study was to compare the effectiveness of standard synthetic chemical control measures to organic control products for the control of insect pests in cabbage in Saskatchewan. A second goal of this study was to examine the efficacy of alternative approaches to pest control such as companion planting, application of plant derived essential oils or use of crop covers. The efficacy of these treatments was assessed by evaluating their effect on pest populations, crop yield and crop quality. It was hypothesized that the synthetic pesticides would provide the most effective insect control, resulting in higher yield and better quality, although these products raise questions about food safety and environmental health. The potential effectiveness of the herbal products was largely unknown.

\section{Materials and Methods}

\section{Field Site Information and Preparation}

The experiment was conducted in 2015 at the University of Saskatchewan Horticulture Field Research Station in Saskatoon, Saskatchewan. The trial site has been repeatedly cropped to cruciferous vegetables and is within one kilometer of commercial canola fields, resulting in a build-up of root maggot, flea beetle, cabbage looper and imported cabbage worm populations at the test site (Waterer et al. 2015).

The test site was prepared in early May by rotovating the soil, at which time enough nitrogen fertilizer (Keg Agro, Broderick, Saskatchewan) was incorporated to raise the total soil nitrogen level to the recommended rate for cabbage of $100 \mathrm{~kg} / \mathrm{ha}$. All other nutrients were already present in the soil in adequate quantities for cabbage production. The herbicide Treflan $(480 \mathrm{~g} / \mathrm{L}$ of trifluralin; Dow AgroSciences, Calgary) was applied to the soil surface at the recommended rate of $2.2 \mathrm{~L} / \mathrm{ha}$ and then lightly incorporated by rotovating just prior to transplanting out or seeding the test crop.

\section{Transplanted Trial}

Cabbage transplants were produced in the University of Saskatchewan Agriculture Greenhouse in Saskatoon. The cultivar Bravo (Harris Seeds, Rochester, New York) was selected as it is a mid-season cultivar known to produce uniform, moderately sized heads. Bravo has performed well in previous trials conducted by the Vegetable Crops Research Program at the University of Saskatchewan (University of Saskatchewan 2009). The cabbage was seeded into Sunshine Mix \#4 (Sun Gro Horticulture, Agawarm, Massachusetts) on April 27. The seedlings were grown for 30 days in a glass greenhouse at $24^{\circ} \mathrm{C}$ day, $18^{\circ} \mathrm{C}$ night with 16 hour day and 8 hour night periods.

The cabbage seedlings were transplanted into the field on May 27 using a Water Wheel type transplanter (Rain-Flo Irrigation, East Earl, Pennsylvania). This machine spaced the seedlings at $30 \mathrm{~cm}$ within the row in rows spaced $1.25 \mathrm{~m}$ apart. The seedlings were watered in with a 10-52-10 fertilizer solution (Plant Products, Leamington, Ontario) diluted to $100 \mathrm{ppm}$ nitrogen. Seven treatments of a single row each were planted with ten plants per row. Each treatment was replicated three times. Treatments were arranged in a randomized complete block design, the standard design for agricultural experiments as it minimizes variation within the field and unintentional bias due to arrangement of treatments (Davis et al. 2012). Guard rows were planted on the outside of the plot to act as a buffer and minimize any effects caused by neighbouring test plots (Davis et al. 2012). One guard row in each replicate was covered with row cover to create an eighth treatment.

\section{Direct Seeded Trial}

The direct seeded trail was seeded on June 2 using a push-type small plot seeder (Jang Automation, Korea). Seeds were planted into moisture at a depth of $1.5 \mathrm{~cm}$. The cultivar Hinova (Bejo Seeds Inc., Oceano, California) was selected for this trial because it has many of the same attributes as Bravo, a vigorous, mid-season variety with uniform, high quality heads. The direct seeded cabbage 
crop emerged quickly under environmental conditions near ideal for germination. Seedlings were thinned to one plant every $15 \mathrm{~cm}$ at the three true leaf stage. Each treatment row in the direct seeded trial was $3 \mathrm{~m}$ long and row spacing was $1.25 \mathrm{~m}$. The rows were thinned ten plants per row on August 5 . The direct seeded experiment consisted of seven treatments in a randomized complete block design with three replicates.

\section{Treatments, Formulations and Application Schedule}

The pest control treatments for both the transplanted and direct seeded cabbage crops were:

Treatment 1 - untreated control

Treatment 2 - treated with conventional insecticides

Treatment 3 - treated with organic pest control products

Treatment 4 - garlic companion plants

Treatment 5 - sprayed with a garlic oil/water emulsion

Treatment 6 - thyme companion plants (transplanted trial only)

Treatment 7 - sprayed with a thyme oil/water emulsion

Treatment 8 - row cover

The control treatment was grown without any applied pesticides and no other pest control measures were used.

The conventional spray treatment consisted of chlorpyrifos (Lorsban ${ }^{\circledR} 480 \mathrm{~g} / \mathrm{L} ;$ Dow AgroSciences, Calgary) applied for root maggot control and deltamethrin (Decis ${ }^{\circledR}$ 50g/L; Bayer CropScience, Calgary) and lambda-cyhalothrin (Matador ${ }^{\circledR}$ 120g/L; Syngenta Canada Inc., Guelph) applied for control of flea beetles and cabbage worms. All pesticides were applied at label recommended rates. Chlorpyrifos was applied as a post-planting drench at the rate of $21.2 \mathrm{~mL}$ of product per $100 \mathrm{~m}$ of row. In the transplanted trial chlorpyrifos was applied three times at two week intervals, with the first application five days after the seedlings were transplanted into the field. In the direct seeded trial chlorpyrifos was applied twice, two weeks apart, with the first application occurring three days after the majority of cabbage seedlings had emerged. In both trials the drench was applied using a small carbon dioxide driven plot sprayer with 80-08 flood nozzles, which delivered the product over a $15 \mathrm{~cm}$ wide spray band. Deltamethrin was applied at $1 \mathrm{~mL}$ product/L and lambdacyhalothrin was applied at $0.3 \mathrm{~mL}$ product/L. Both insecticides were applied at a rate of $40 \mathrm{~L} / \mathrm{ha}$ using a carbon dioxide powered back pack sprayer fitted with 80-01 nozzles. These products were applied at two week intervals starting with an application of deltamethrin on July 14, followed by another application of deltamethrin on July 27, an application of lambda-cyhalothrin on August 12 and a final application of deltamethrin on August 25.
The organic treatment used parasitic nematodes (Steinernema feltiae; Biobest, Leamington, ON) to control root maggots. Nematodes suspended in water were applied as a soil drench. A watering can was used to apply approximately $0.3 \mathrm{~L}$ to each plant, resulting in approximately 750,000 nematodes applied to each plant at each application. The plot was irrigated immediately after nematode application to move the nematodes into the root zone. Nematodes were applied at two week intervals beginning five days after the seedlings were transplanted into the field in the transplanted trial and three days after emergence in the direct seeded trial. Spinosad (Success ${ }^{\circledR}$ $480 \mathrm{~g} / \mathrm{L}$; Dow AgroSciences, Calgary) and Btk (Bacillus thuringiensis subsp. Kurstaki strain ABTS-51; Woodstream Canada Corporation, Brampton, ON) were used to control cabbage worms in the organic treatment. Spinosad was applied at the rate of $3 \mathrm{~mL}$ product/L at $40 \mathrm{~L} / \mathrm{ha}$. Btk was also applied at $3 \mathrm{~mL}$ product/L at $40 \mathrm{~L} / \mathrm{ha}$. Spinosad and Btk sprays were alternated at two week intervals. Each product was applied twice, beginning with Spinosad on July 14, with applications falling on the same dates as those in the conventional pesticide treatment. The Spinosad and Btk spray solutions were applied using a carbon dioxide powered back pack sprayer with 80-01 nozzles.

For the garlic companion treatment three garlic plants were transplanted between each cabbage transplant on May 28. The garlic companion plants for the transplanted trial were started on April 27 from cloves supplied by the University of Saskatchewan Vegetable Program. Thyme companion plants were started from seed (Stokes Seeds Ltd, Thorold, ON) on March 31. Both types of companion plants were grown under the same greenhouse conditions as the cabbage transplants. Companion plants were only placed within the row and, due to weed control issues, not placed to the sides of the cabbage plants. For the garlic companion treatment in the direct seeded trial, sprouted garlic cloves (Christopher Ranch, Sobey's) were interplanted with the cabbage seedlings on June 26 at three cloves per $30 \mathrm{~cm}$ of row, attempting to place three cloves between each cabbage plant and three cloves at either end of the row. The cabbage seedlings had been thinned prior to planting the garlic cloves.

The garlic oil treatment used an emulsion of $0.1 \mathrm{ml}$ of garlic oil (Plant Therapy Essential Oils, Twin Falls, Idaho) in $100 \mathrm{ml}$ of water with $0.5 \mathrm{ml}$ of Vayselle liquid dish detergent (Dustbane, Ottawa) as an emulsifier. The thyme oil treatment used an emulsion of $0.1 \mathrm{ml}$ of thyme oil (Fabulous Frannie, Temecula, California) in $100 \mathrm{ml}$ of water with $0.5 \mathrm{ml}$ of Vayselle liquid dish detergent as an emulsifier. The essential oils were applied once a week, based on a study by Zehnder et al. (1997) in which good control of cabbage pests was achieved using a weekly spray schedule of organic sprays. The essential oils were applied using a standard hand-held mister-type spray bottle. 
Approximately $1.3 \mathrm{~mL}$ of emulsion was applied to the base of the plants the first week after transplanting, followed by $1.3 \mathrm{~mL}$ to the base of the plant and $1.3 \mathrm{~mL}$ to the growing tip once a week for the next five weeks. As the plants grew they required a greater volume of product to achieve coverage. Therefore, the transplanted cabbage crop was treated with $1.3 \mathrm{~mL}$ of essential oil emulsion to the base of the plant and $2.6 \mathrm{~mL}$ to the developing head for one week, followed by $2.6 \mathrm{~mL}$ to the head of the cabbage for the next three weeks, until harvest. The direct seeded cabbage plants were treated with $1.3 \mathrm{~mL}$ of emulsion to the emerging seedlings for the first three weeks, starting June 11. For the next four weeks the essential oil emulsion application was directed at the base of the seedlings, with $1.3 \mathrm{~mL} /$ plant applied at each application. The direct seeded plants were treated with $2.6 \mathrm{~mL}$ of emulsion per plant, directed at the developing head, for the next nine weeks.

The row cover treatment used was a white agrotextile, Agryl $\mathrm{P}_{17}$ (Fiberweb France, Biesheim France) designed to keep insect pests away from the cabbage crop. Thin metal arches were used to support the row cover above the cabbage plants to avoid damaging the growing points of the crop. The edges of the row cover were covered in soil to prevent access by insects and rodents.

\section{Trial Maintenance}

Plots were kept weed free using mechanical tillage and hand weeding. The plots were irrigated weekly using a wheel move system. A top-dress treatment of urea fertilizer (46-0-0) was applied in early July to supply an additional $22.4 \mathrm{~kg} / \mathrm{ha}$ of nitrogen to the transplanted crop. The plot was irrigated immediately after fertilizer application to move the nitrogen into the root zone.

\section{Data Collection}

Flea beetle damage was rated as a percentage of the cotyledon area damaged by flea beetle feeding (Canola Council of Canada 2011). Root maggot damage was rated by a visual count of the number of eggs on three randomly selected plants within each row. Egg counts were taken on June 9 and June 23. The number of plants that died as a result of root maggot feeding was also recorded on July 8 . At harvest time the heads of cabbage were weighed as an indirect measure of root maggot damage, as more heavily damaged plants will produce smaller heads than those that were not damaged (Alberta Agriculture and Forestry 2002). Cabbage worm damage was evaluated at the final harvest by weighing all heads in each treatment to obtain the total yield for each treatment. Five heads were then chosen randomly from within each row for further evaluation. In rows where there were five heads or less harvested due to cabbage plant fatalities, all heads were further evaluated. These heads were weighed and then trimmed to remove any leaves showing cabbage worm damage. The heads were then re-weighed. The amount of weight lost due to trimming was recorded as an evaluation of the severity of cabbage worm damage.

\section{Data Analysis}

Data analysis was carried out using Microsoft Excel. Statistical significance was determined by one-way analysis of variance at the $5 \%$ significance level. The least significant difference test was used for mean separation. Percentage data were transformed using arcsin(\%) before analysis and treatment means were back transformed for presentation.

\section{Results}

There was a frost of $-3^{\circ} \mathrm{C}$ on May 29 , two days after the cabbage seedlings were transplanted into the field. The frost killed some plants and damaged others. There was also flea beetle pressure early in the development of the transplanted trial as well as problems with rabbit and deer feeding. On June 9 any dead or eaten seedlings were replaced with reserve transplants. The transplanted crop had recovered by late June and there were no more problems observed aside from the expected insect pests.

The direct seeded crop went into moist field conditions and temperatures in the two weeks following seeding were above the 30-year historical average. In cases where fewer than 10 seedlings emerged within a row, extra cabbage seedlings from the guard row were transplanted to ensure each row had 10 healthy cabbage plants. Root maggot and flea beetle pressure was minimal in the direct seeded trial. Cabbage worm pressure began in early July and was high in both the direct seeded and transplanted crops until the crops were ready for harvest.

\section{Flea Beetle Damage}

Flea beetle damage could not be accurately assessed in the transplanted trial due to damage by a late spring frost and rabbit and deer feeding damage to the newly transplanted cabbage seedlings. Flea beetle pressure was low in the direct seeded trial. No treatment had flea beetle damage covering more than $10 \%$ of the cotyledon area (Figure 1). The established action threshold in canola and mustard is $25 \%$ damage, however a range of $10-30 \%$ has been suggested for vegetable crops (Canola Council of Canada 2014b, Burkness and Hahn 2007). No significant results were found. 


\section{Root Maggot Damage}

There were no statistically significant differences among the treatments in the transplanted trial for the number of root maggot eggs counted at the base of the cabbage transplants at either the June 9 or June 25 sampling dates. The differences in cabbage plant fatalities due to root maggot. among the treatments in the transplanted trial was also not statistically significant.

However, it was highly variable and therefore data are presented in Figure 2. The standard pesticide and covered treatments both prevented any fatalities due to root maggot damage. Low levels of root maggot pressure were observed in the direct seeded trial as the crop emerged after the peak period of egg laying by root maggot flies. No fatalities due to root maggot damage were observed in the direct seeded trial. Therefore, no data regarding root maggot damage are presented from the direct seeded trial.

Figure 1: Effect of insect control treatments on flea beetle damage to cotyledons in direct seeded cabbage. Vertical bars represent the standard errors of the means.

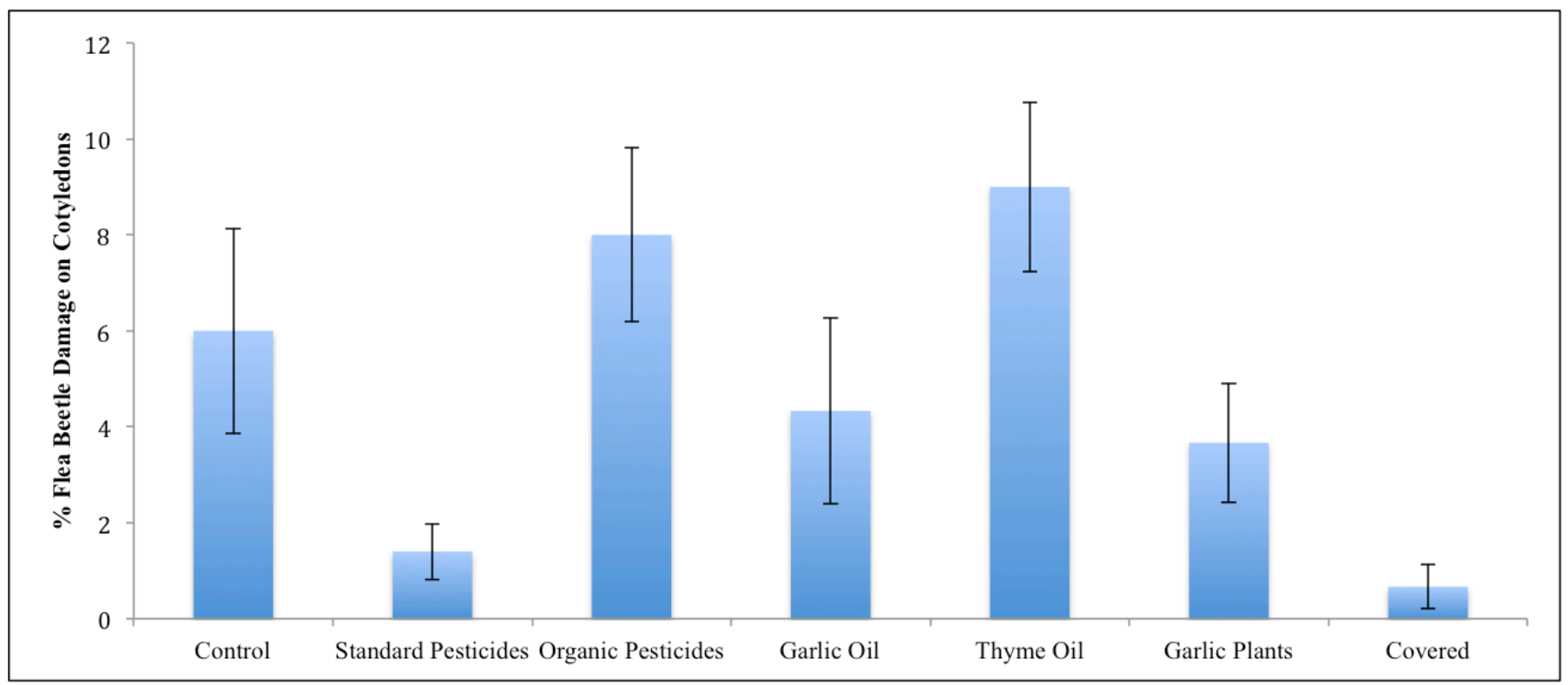

Figure 2: Effect of insect control treatments on cabbage plant mortality in transplanted cabbage. Vertical bars represent the standard errors of the means.

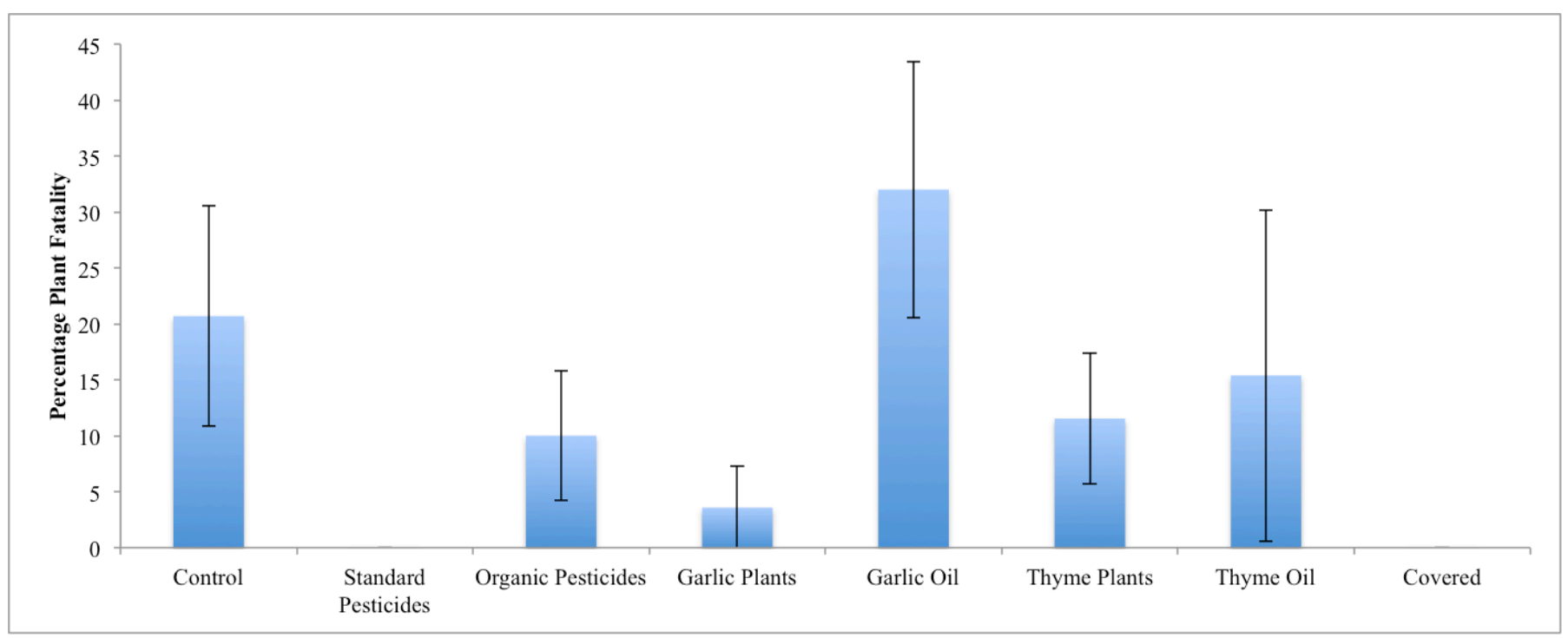

University of Saskatchewan Undegraduate Research Journal 


\section{Cabbage Worm Damage}

The standard pesticide treatment resulted in the greatest yield, which was significantly greater than any of the herbal treatments, but not significantly different from the organic pesticide, covered or control treatment (Figure 3). There were no significant differences among herbal control treatments. All four of the herbal treatments resulted in lower yields relative to the control treatment, although this was only statistically significant in the garlic oil treatment.

There were significant differences in marketable head weight among the different treatments in the transplanted trial. The standard pesticide treatment resulted in significantly higher marketable head weights than the herbal treatments, although it was not different than the organic pesticide treatment and only the row cover resulted in significantly higher marketable yields than the control (Figure 4). There were no significant differences in the percentage of head weight lost due to trimming.

There was no difference among treatments in total yield in the direct seeded trial with the exception of the covered treatment, which had a significantly lower yield than the control, standard and organic pesticide treatments and the garlic companion plant treatment (Figure 5). The standard and organic pesticide treatments resulted in significantly higher marketable head weights, obtained by trimming damaged leaves from the cabbage heads, than the control in direct seeded cabbage (Figure 6). There was no statistical difference in marketable trimmed head weights among the herbal treatments in either the transplanted or direct seeded crops (Figures 4 and 6). In the direct seeded trial, there was no statistical difference in marketable head weight between the garlic plants or thyme oil treatments and the organic pesticide treatment (Figure 6).

The standard pesticide, organic pesticide and covered treatments significantly reduced trimming losses due to cabbage worm feeding damage relative to the control treatment (Figure 7). Garlic oil, thyme oil and garlic companion plants did not reduce the amount of head weight lost due to cabbage worm feeding damage when compared to the untreated control treatment, and were also not statistically different from the organic pesticide treatment.

Figure 3: Effect of insect control treatments on yield of transplanted cabbage. Yield is per ten cabbage transplants. Vertical bars represent the standard errors of the mean. Treatments with the same letter are not statistically different $(p=$ $0.05, n=3$ ) according to the LSD test.

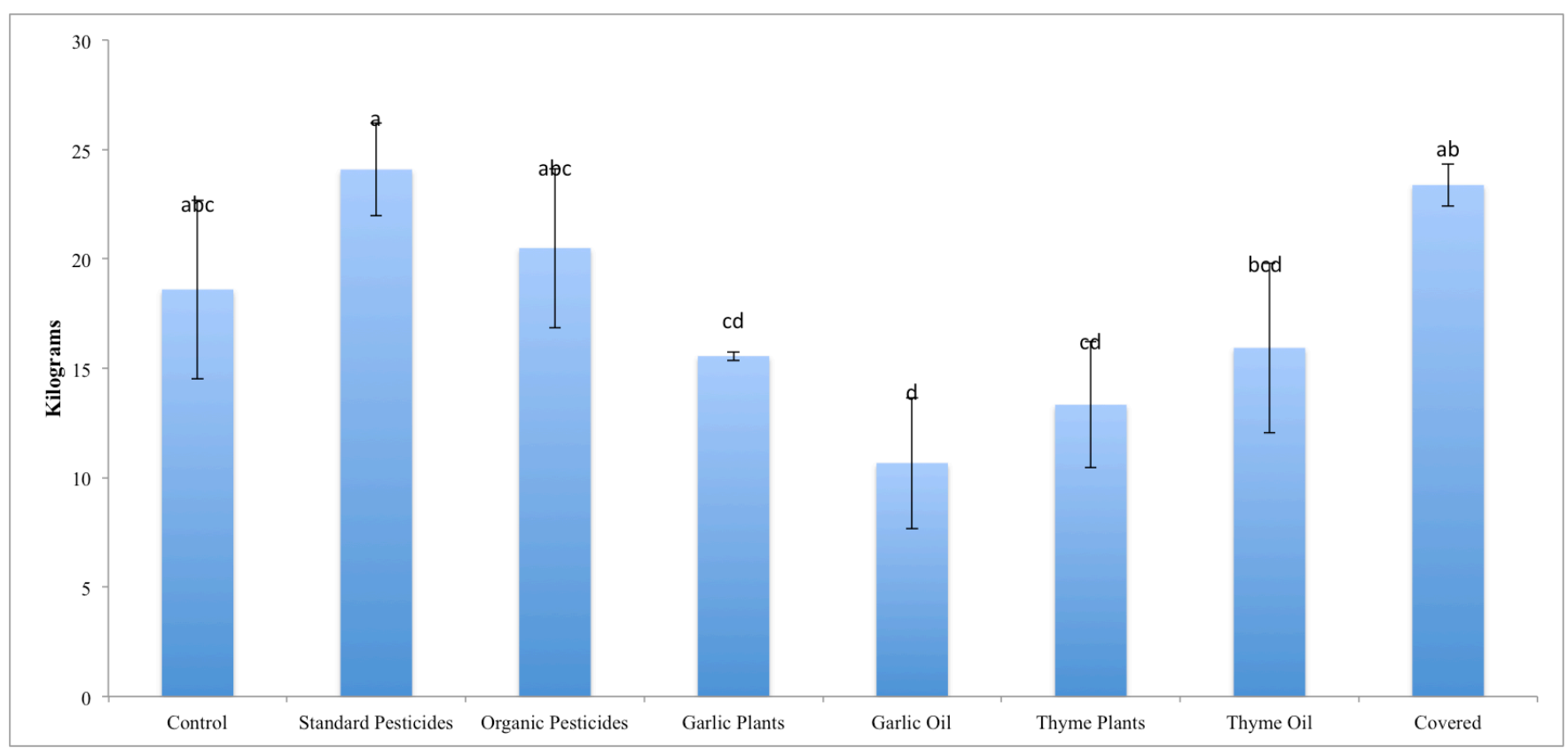


Figure 4: Effect of insect control treatments on head weight and weight lost to trimming in transplanted cabbage. Vertical bars on the treatment columns represent the standard errors of the mean of the marketable weight. Vertical bars to the right of the treatment columns represent the standard errors of the mean for trim loss. Treatments with the same letter are not statistically different $(p=0.05, n=3)$ according to the LSD test. Lowercase letters denote statistical significance for untrimmed head weight and uppercase letters denote statistical significance for marketable head weight.

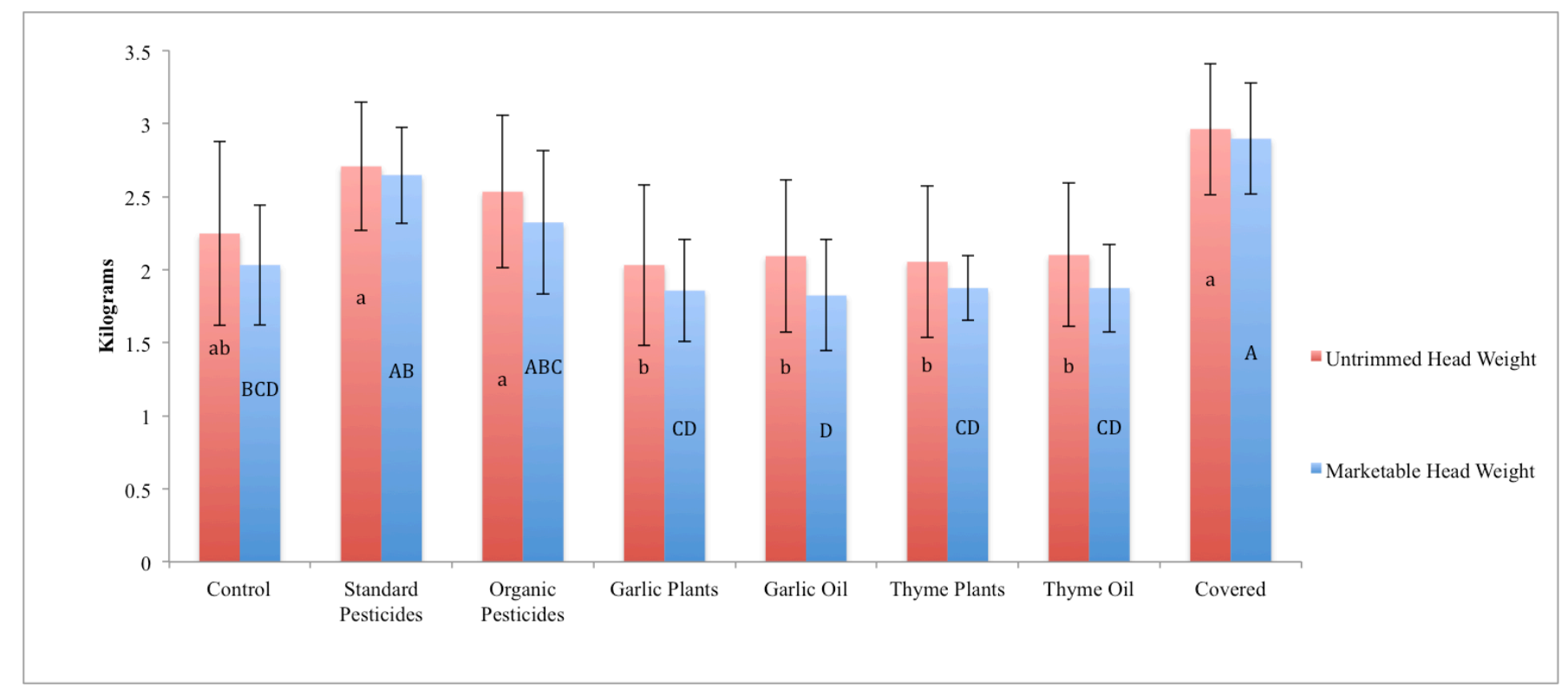

Figure 5: Effect of insect control treatments on yield of direct seeded cabbage. Yield is per ten cabbage plants. Vertical bars represent the standard errors of the mean. Values with the same letter are not significantly different $(P=0.05, n=3)$ according to the LSD test.

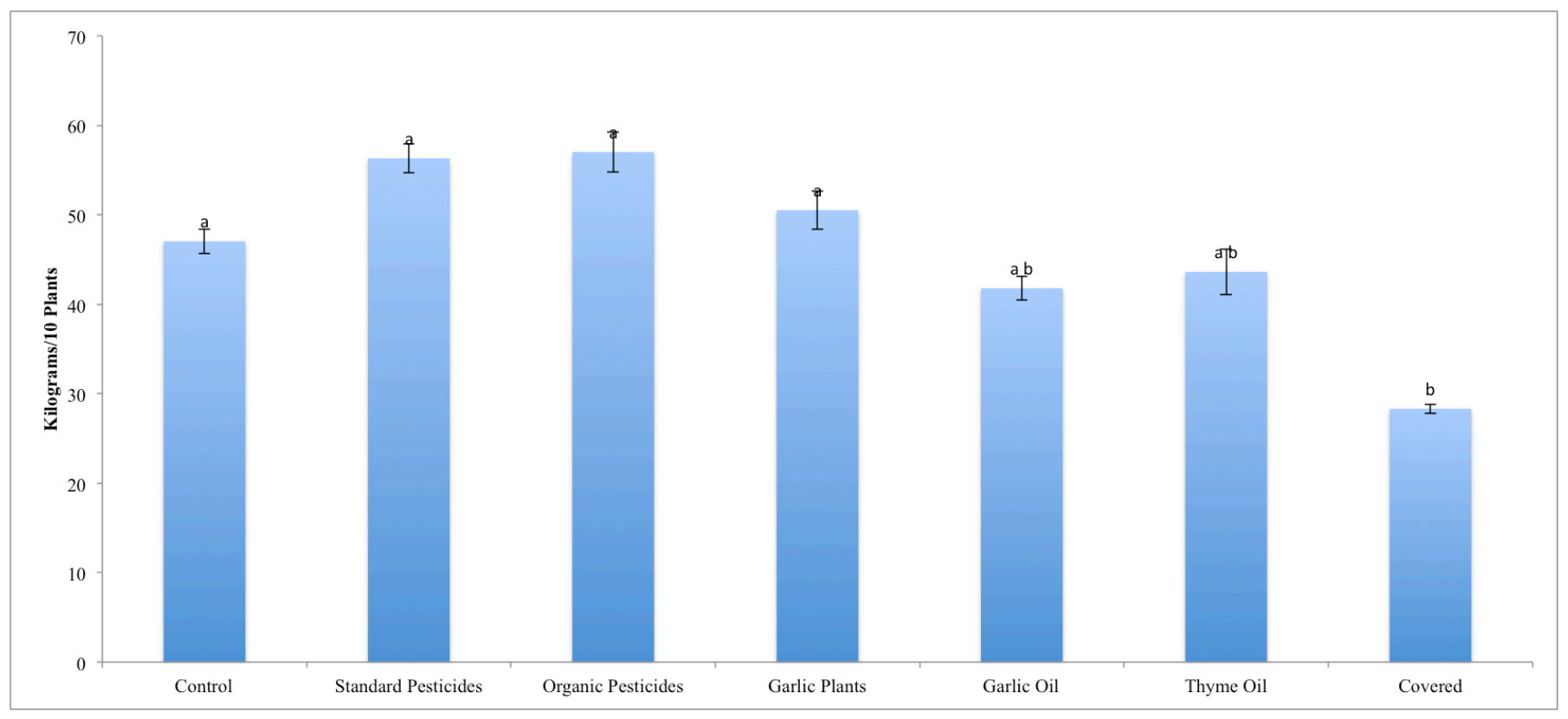


Figure 6: Effect of insect control treatments on head weight and weight lost to trimming in direct seeded cabbage. Vertical bars represent the standard errors of the mean. Values with the same letter are not significantly different $(P=0.05$, $\mathrm{n}=15$ ) according to the LSD test.

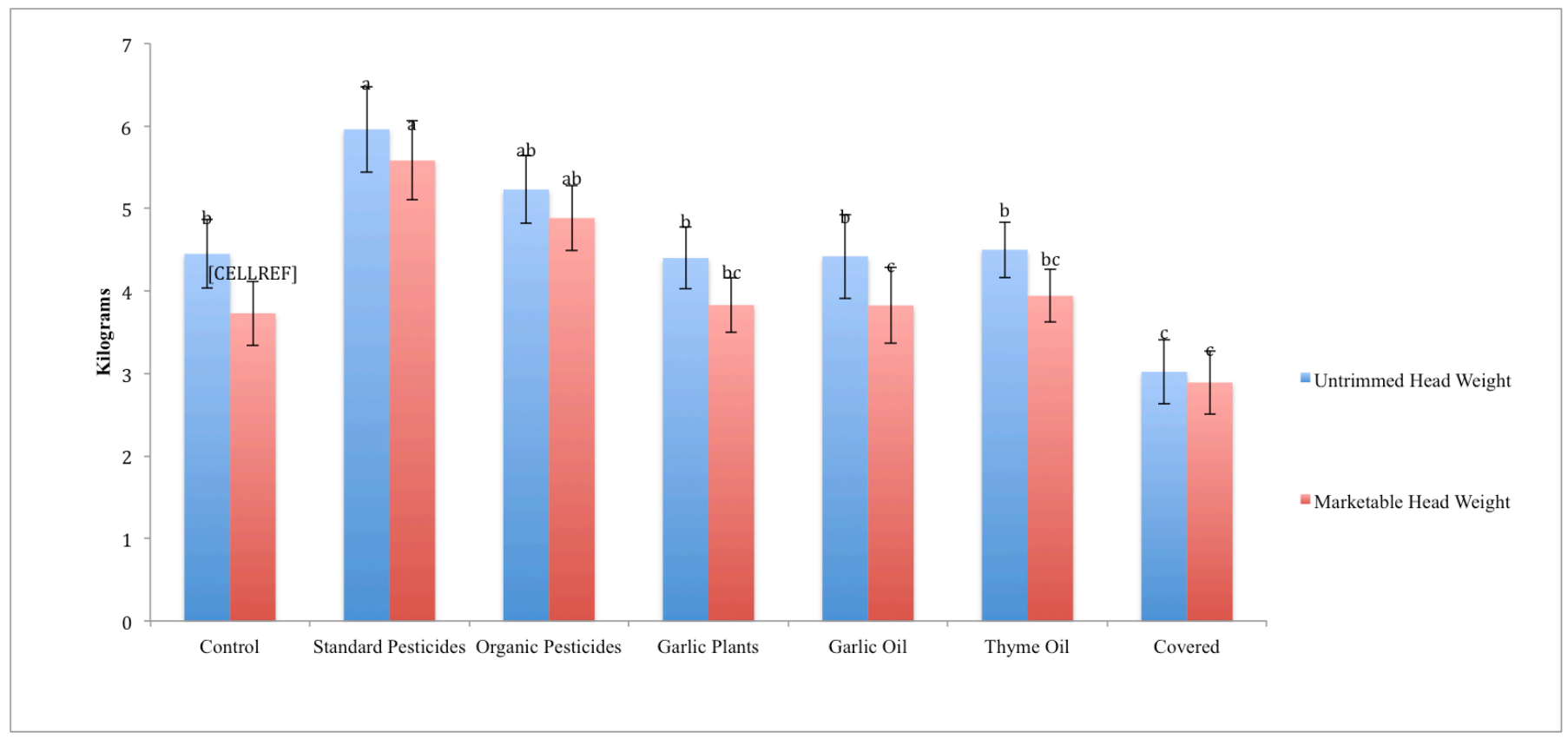

Figure 7: Effect of insect control treatments on head weight loss due to trimming in direct seeded cabbage. Vertical bars represent the standard errors of the mean. Values with the same letter are not significantly different $(P=0.05, n=3)$ according to the LSD test.

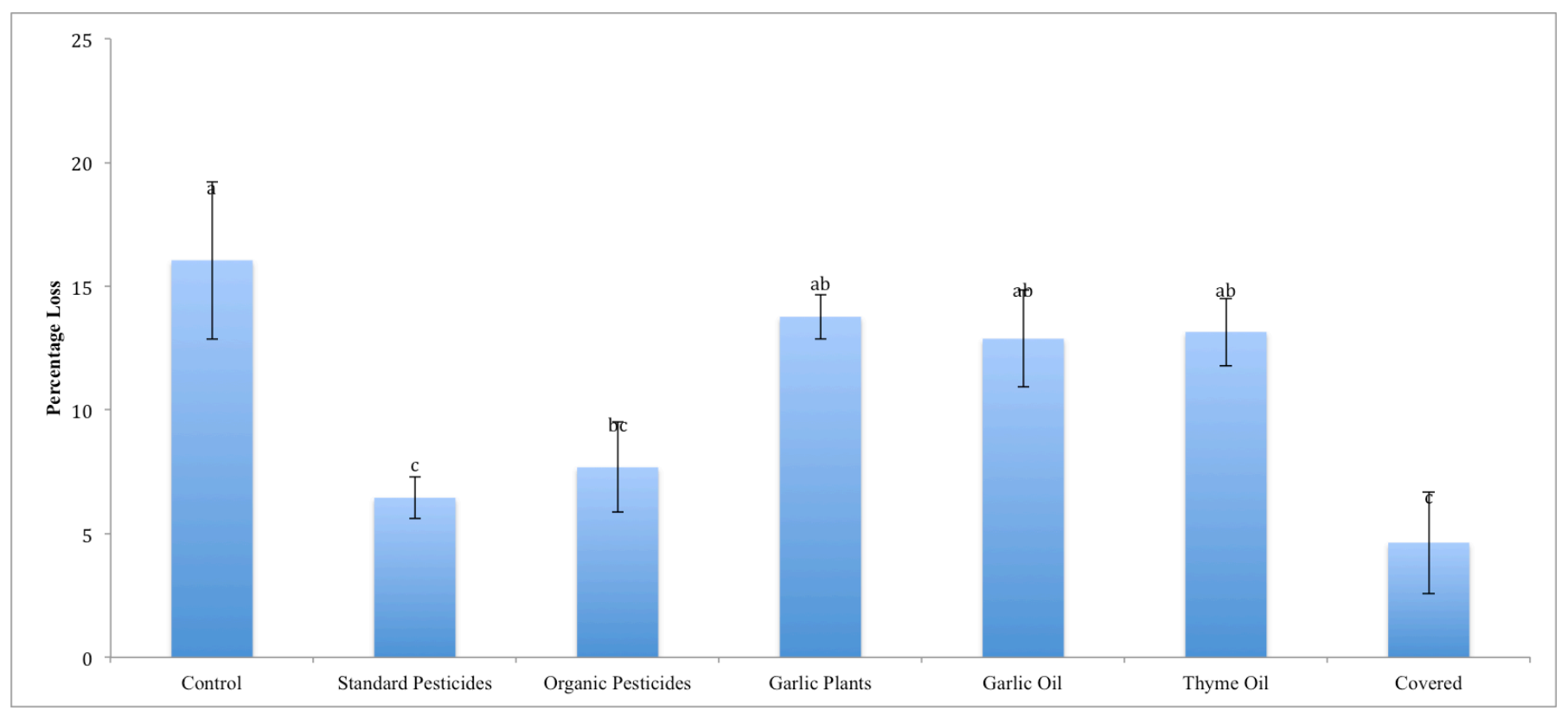




\section{Discussion}

The standard and organic pesticide treatments performed equally well in both transplanted and direct seeded cabbage crops. In the transplanted trial, the organic pesticide was not as effective as the standard pesticide at preventing plant loss due to root maggot damage, however the stand loss was not severe enough to decrease yields significantly. The control of cabbage worms achieved with the organic products was comparable with the standard synthetic pesticides in both the transplanted and direct seeded trials. The yield of the organic pesticide treatment was about $16 \%$ lower than the standard pesticide regime in the transplanted trial but was nearly the same as the standard pesticide treatment in the direct seeded trial. These differences were not found to be significant. A full costbenefit analysis is needed to determine any economic benefits to organic cabbage production in Saskatchewan, as organic produce commands a price premium, but the organic pest control products are considerably more expensive than the standard synthetic pesticides. For example, the rate of nematodes applied as part of the organic pesticide regime cost $\$ 7000$ per acre per application, an unrealistic expense for a commercial grower.

In both the transplanted and direct seeded trials, covering the cabbage plants with row cover material proved very effective at preventing damage by all three of the insect pests evaluated in this project. Losses due to trimming in the row cover treatment were the same as in the standard and organic pesticide treatments, but keeping cabbage covered for an extended period of time is impractical on a field scale. Weed control under the cover treatment was particularly problematic. The cover had to be removed to allow weeding and then replaced, requiring extra labour and driving up production costs. In addition, insects quickly discovered any tear or gap in the cover, leading to low levels of damage. Keeping the crop covered resulted in higher total and marketable yields than the control treatment in the transplanted trial. This yield increase could be attributed to the warmer conditions underneath the row cover enhancing growth during the cooler periods in spring and early summer or the reduced rate of evapotranspiration due to the shading effect of the cover. However, covering the crop significantly reduced total yield and had no effect on average marketable head weight compared to the control. The temperatures under the row cover may have exceeded the optimum growing temperature range for cabbage during the warm days of mid-summer, resulting in reduced growth of the cabbage plants. Row covers could be an effective pest management choice for the home gardener, but at a considerable added cost. Waterer (1992) estimated the cost of materials required to cover vegetable crops exceeds $\$ 2500 / a c$, not including the labour required to construct and remove the covers.

Using aromatic plants such as garlic and thyme as companion plants or spraying with an oil-in-water emulsion of essential oils derived from the companion plants did not control any of the insect pests considered in this project. Garlic oil appeared to have increased insect damage on the cabbage crop; it resulted in significantly decreased yield in the transplanted trial and significantly decreased marketable head weight in the direct seeded trial. This is in contrast to the findings of Zehnder et al. (1997), who showed that a foliar applied garlic treatment reduced cabbage worm populations and feeding damage compared to a control treatment. The difference may lie in the type of garlic extract used; Zehnder et al. (1997) used a spray containing garlic juice, whereas this study used a spray containing garlic oil. The dish soap used as an emulsifier in this experiment may have also contributed to the treatment's inefficacy. It is not recommended to use garlic oil in the manner outlined in this project as it was both ineffective and unpleasant to work with due to its strong, persistent odour.

The thyme oil treatment was generally ineffective at controlling any of the pests evaluated in this project. The lack of positive results from the essential oil treatments was unexpected, as contact with thyme oil has been shown to be lethal to T. ni larvae (Machial et al. 2010; Jiang et al. 2010; Tak et al. 2015). Perhaps the concentration of thyme oil used in the spray was too low to effectively control $T$. ni in a field setting. A higher rate of thyme oil should be tested, but attention should be paid to any potential toxicity to the crop and unpleasant odour residues that might remain on the harvested product.

Neither the garlic nor thyme companion plants protected the cabbage crop from insect pests. Both the garlic and thyme companion plant treatments resulted in yields and pest damage levels similar to the control, with no significant differences found. Surrounding the cabbage on all sides with companion plants or simply planting more companion plants in between the cabbage plants may increase their efficacy as they may be better able to mask the chemical signals coming from the cabbage plants. However, this would increase the cost and labour requirements of using companion plants. Increasing the number of companion plants present may also increase competition between the companion plants and the crop. Herbicide compatibility must also be considered. The companion plants used in this project necessitated hand weeding as there are no herbicides registered for use on both cabbage and garlic or cabbage and thyme.

More studies are needed to accurately assess the various treatments' effectiveness against flea beetles. A 
late spring frost as well as deer and rabbit feeding damaged the transplanted trial to the point that flea beetle damage could not be accurately determined. Due to the late seeding date, the direct seeded trial largely escaped flea beetle feeding with no treatment having more than $10 \%$ cotyledon area damaged by flea beetles. Similarly, the late seeding date caused the direct seeded cabbage crop to emerge after peak root maggot egg laying, resulting in almost no damage to the direct seeded cabbage seedlings due to root maggot feeding.

\section{Conclusions}

As hypothesized, a regime based on timely application of a range of standard pesticides provided very effective control of flea beetles, root maggots and cabbage worms. The organic pesticide regime proved effective at controlling insect pests of cabbage and produced marketable yields equal to the standard pesticides. Nematodes as a biocontrol agent for root maggots, which was tested as part of the organic pesticide regime, should be further studied in field trials to determine the most efficient rates of application and the economic feasibility of applying nematodes under field conditions. The added cost of using organically acceptable products may be offset by the price premium commanded by organically grown produce. The row cover treatment was effective at preventing insect damage, but also created management issues such as increased labour and care required when weeding. Row covers are not practical on a large scale, but may be suited to backyard gardeners. The thyme and garlic companion plants and essential oil sprays proved ineffective against any of the insect pests of cabbage evaluated.

This study demonstrated that organic control of insect pests of cabbage is possible in Saskatchewan. Growers could try using organic pesticides to increase the number of products in their pesticide rotation on their cruciferous crops to prevent insect resistance to the standard insecticides presently relied on to produce good quality cruciferous vegetable crops. However, with the exception of Btk, the organic control products used in this study are not available to backyard gardeners. The herbal control methods tested in this project must be modified so that they offer greater insect pest control. For example, planting orientations or essential oils other than those tested in this project may offer better control of certain insect pests. Modifying the herbal control methods tested here could be the focus of future projects.

\section{References}

Alberta Agriculture and Forestry. 2002. Cabbage maggot. [Online]

Available: http://www1.agric.gov.ab.ca/\$department /deptdocs.nsf/all/agdex3509 [2017 Jan. 20]

Agriculture and Agri-Food Canada. 2015. Reduced-risk strategy for cabbage maggot management in brassica crops. [Online]

Available: http://www.agr.gc.ca/eng/?id=13014983881 81 [2016 Jan. 24].

Arce-Lopera, C., Masuda, T., Kimura, A., Wada, Y., Okajima, K. 2013. Luminance distribution as a determinant for visual freshness perception: Evidence from image analysis of a cabbage leaf. Ninth Pangborn Sensory Science Symposium. Food Qual. Pref. 27(2): 202-207.

Bracken, G. K. 1990. Susceptibility of first-instar cabbage maggot, delia radicum (L.) (anthomyiidae: Diptera), to strains of the entomogenous nematodes steinernema feltiae Filipjev, S. bibionis (bovien), heterorhabditis bacteriophora poinar, and $H$. heliothidis (khan, brooks and hirschmann). Can. Entomol. 122(4): 633-639.

Broatch, J. S., Dosdall, L. M., Clayton, G. W., Harker, K. N., Yang, R. 2006. Using degree-day and logistic models to predict emergence patterns and seasonal flights of the cabbage maggot and seed corn maggots (Diptera: Anthomyiidae) in canola. Environ.

Entomol. 35(5): 1166-1177.

Bruce, T. J. A., Wadhams, L. J., Woodcock, C. M. 2005. Insect host location: a volatile situation. Trends Plant Sci. 10(6): 269-274.

Burkness, S., Hahn, J. 2007. Flea beetles in home gardens. University of Minnesota. [Online] Available: http://www.extension.umn.edu/garden/insects/find/fl ea-beetles/ [2017 Jan 2].

Campbell, B. L., Mhlanga, S., Lesschaeve, I. 2013. Perception versus reality: Canadian consumer views of local and organic. Can. J. Ag. Econ. 61(4): 531558. 
Canadian Food Inspection Agency. 2013. Cabbage.

[Online]

Available: http://www.inspection.gc.ca/food/fresh-

fruits-and-vegetables/quality-inspection/vegetableinspection-

manuals/cabbage/eng/1303752495748/1303752563262

[2016 Jan. 14].

Canadian General Standards Board. 2015. Organic production systems general principles and management standards. Canadian General Standards Board: Gatineau, QC.

Canola Council of Canada. 2014a. Diamondback moth. [Online] Available: http://www.canolacouncil.org/canolaencyclopedia/insects/diamondback-moth/ [2016 Jan 25].

Canola Council of Canada. 2014b. Flea beetles. [Online] Available: http://www.canolacouncil.org/canolaencyclopedia/insects/flea-beetles/ [2016 Jan 15].

Canola Council of Canada. 2011. Estimating flea beetle damage in canola. [Online]

Available: http://www.canolawatch.org/2011/05/og/es timating-flea-beetle-damage-in-canola/ [2016 Jan 7].

Davis, R.F., Harris, G.H., Roberts, P.M., MacDonald, G.E. 2012. Designing research and demonstration tests for farmers' fields. University of Georgia, Cooperative Extension. [Online] Available: http://extension.uga.edu/publications/files/pdf/B\%201 177_3.PDF [2017 Jan. 20]

Ecological Agriculture Projects. Undated. Conquer cabbage patch pests. McGill University, MacDonald Campus. [Online] Available:

http://eap.mcgill.ca/CPCM_8.htm [2016 Jan 26].

Ester, A., de Putter, H., van Bilsen, J.G.P.M. 2003. Filmcoating the seed of cabbage (Brassica oleracea $L$. convar. Capitata L.) and cauliflower (Brassica oleracea L. var. Botrytis L.) with imidacloprid and spinosad to control insect pests. Crop Prot. 22(5): 761-768.

Finch, S., Billiald, H., Collier, R. 2003. Companion planting - do aromatic plants disrupt host-plant finding by the cabbage root fly and the onion fly more effectively than non-aromatic plants? Entomol. Exper.

Applic. 109: 183-195.
Kirst, H.A. 2010. The spinosyn family of insecticides: realizing the potential of natural products research. J. Antibiotics. 63: 101-111.

Henderson, A.E., Hallett, R.H., Soroka, J.J. 2004. Prefeeding behaviour of the crucifer flea beetle, Phyllotretea cruciferae, on host and nonhost crucifers. J. Insect Behavior. 17: 17-39.

Janmaat, A. F., Myers, J. 2003. Rapid evolution and the cost of resistance to Bacillus thuringiensis in greenhouse populations of cabbage loopers, Trichoplusia ni. Proc. Bio. Sci. 270(1530): 22632270.

Jiang, Z. L., Akhtar, Y., Zhang, X., Bradbury, R., Isman, M. B. 2010. Insecticidal and feeding deterrent activities of essential oils in the cabbage looper, Trichoplusia ni (Lepidoptera:Noctuidae). J. Appl. Entomol. 136: 191-202.

Kergunteuil, A., Cortesero, A. M., Chaminade, V., Dourlot, S., Paty, C., Le Ralec, A., Dugravot, S. 2015. Field and laboratory selction of brassicaceous plants that differentially affect infestation levels by Delia radicum. J. Appl. Entomol. 139: 487-495.

Leger, C., Riga, E. 2009. Evaluation of marigolds and entomopathogenic nematodes for control of the cabbage maggot Delia radicum. J. Sustain. Agri. 33(2): 128-141.

Machial, C., Shikano, I., Smirle, M., Bradbury, R., Isman, M. 2010. Evaluation of the toxicity of 17 essential oils against Choristoneura rosaceana (lepidoptera: Tortricidae) and Trichoplusia ni (lepidoptera: Noctuidae). Pest Manage. Sci. 66: 1116-1121.

National Pesticide Information Center. 2009. Chlorpyrifros technical fact sheet. Oregon State University. [Online] Available: http://npic.orst.edu/factsheets/archive/chlorptech.ht $\mathrm{ml}$ [2016 Feb 18].

\section{Ontario Ministry of Agriculture and} Food. 2013. Vegetable crop protection guide 20142015. Government of Ontario, Toronto, ON.

Pesticide Risk Reduction Program. 2014. Crop profile for brassica vegetables in Canada, 2012. Agriculture and Agri-Food Canada, Ottawa, ON. 
Pest Management Regulatory Agency. 2000. Fact sheet on the Bacillus thuringiensis subspecies kurstaki. Pest Management Regulatory Agency, Ottawa. [Online] Available:

http://publications.gc.ca/collections/Collection/H1132-6-2000E.pdf [2016 Feb 18].

Pest Management Regulatory Agency. 2007. Update on the re-evaluation of chlorpyrifos. Pest Management Regulatory Agency, Ottawa, ON.

Philbrick, H., Gregg, R. 1966. Companion plants and how to use them. Devin-Adair Publishers, Old Greenwich, CT.

Richards, O. W. 1940. The biology of the small white butterfly (Pieris rapae), with special reference to the factors controlling its abundance. J. Anim. Ecol. 9(2): 243-288.

Roth, S. 1999. Companion Planting Made Easy in: Companion Planting. Rodale Press, Inc, Emmaus, PA.

Saskatchewan Agriculture and Food. 2005. Cabbage production. [Online]

Available: https://www.saskatchewan.ca/business/agri culture-natural-resources-and-industry/agribusinessfarmers-and-ranchers/crops-andirrigation/horticultural-crops/vegetables/cabbageproduction [2016 Jan 24].

Soroka, J. 1984. Crop development and yield of transplanted and direct-seeded broccoli (Brassica oleracea var italica $\mathrm{Pl}$.) subjected to flea beetle (Coleoptera: Chrysomelidae) Feeding. M.Sc. thesis, University of Manitoba, Winnipeg, MB. 158 pp.

Soroka, J. J., Dosdall, L. M. 2011. Coping with root maggots in prairie canola crops. Prairie Soils Crops J. 4: 24-31.

Statistics Canada. 2015a. Canola area surpassed spring wheat area in Saskatchewan.

Available: http://www.statcan.gc.ca/pub/95-640x/2011001/p1/prov/prov-47-eng.htm [2016 Jan 24].

Statistics Canada. 2015b. Table 001-0013 - area, production and farm gate value of vegetables, annual. [Online]

Available: http://www5.statcan.gc.ca/cansim/a26 [201 6 Jan 24].
Statistics Canada. 2015c. Table 002-0011 - food available in Canada, annual (kilograms per person, per year unless otherwise noted). [Online]

Available: http://www5.statcan.gc.ca/cansim/a26 [201 6 Jan 24].

Tak, J., Jovel, E., Isman, M. B. 2015. Contact, fumigant, and cytotoxic activities of thyme and lemongrass essential oils against larvae and an ovarian cell line of the cabbage looper, trichoplusia ni. J. Pest Sci. (in press).

University of Saskatchewan. 2009. Recommended vegetable cultivars: 1989-2009. University of Saskatchewan, Saskatoon. [Online] Available: http://www.usask.ca/agriculture/plantsci/vegetable/re sources/publication/2oogresources/CVRecommende8 9-09.pdf [2016 Feb 18]

Waterer, D. 2013. New options for control of root maggots (delia sp.) in vegetable crops. University of Saskatchewan, Saskatoon. [Online]. http://www.agriculture.gov.sk.ca/apps/adf/ADFAdmin Report/20080031.pdf [14 Mar 2016].

Waterer, D. 1998. Integrated management of root maggots in vegetable crops. University of Saskatchewan, Saskatoon, SK. [Online] Available: http://www.usask.ca/agriculture/plantsci/vegetable/re sources/journal/ADF94000077.pdf [2016 Mar 15].

Waterer, D. 1992. Influence of planting date and row covers on yields and crop values for bell peppers grown in Saskatchewan. Can. J. Plant Sci. 72(2): 527533 .

Waterer, D., Schaeffer, J. Taylor, L., Taylor, J., Strubey, K., Douville, B. 2015. Vegetable cultivar and cultural trials 2015. University of Saskatchewan, Saskatoon. [Online] Available: http://veg.usask.ca/wpcontent/uploads/2015-Book-book-version.pdf [2016 Feb 18].

Zehnder, G., Simonne, E., Briggs, T., Bannon, J., Ruff, M. 1997. Organic sprays effective for worm control in cabbage and lettuce. High. Agric. Res. 44(3): 14-16 